\title{
Genetic and Non-Genetics Effect on Birth, Weaning, and Yearling Weight of Bali Cattle
}

\author{
A. Gunawan* \& Jakaria \\ Department of Animal Production and Technology, Faculty of Animal Science, Bogor Agricultural University \\ Jln. Agatis Kampus IPB Darmaga, Bogor 16680, Indonesia \\ (Received 25-10-2010; accepted 13-05-2011)
}

\begin{abstract}
ABSTRAK
Penelitian ini bertujuan untuk mempelajari pengaruh genetik dan nongenetik sifat pertumbuhan bobot lahir, bobot sapih, dan bobot setahun sapi Bali. Analisis general linier model (GLM) digunakan untuk mengkaji pengaruh nongenetik. Selanjutnya untuk mempelajari pengaruh genetik, pendugaan nilai heritabilitas dihitung melalui analisis mixed models dengan memasukkan induk dan pejantan sebagai faktor acak dan jenis kelamin, paritas, tahun kelahiran serta musim sebagai pengaruh tetap. Hasil penelitian ini menunjukkan bahwa jenis kelamin tidak berpengaruh terhadap bobot lahir dan bobot sapih, tetapi berpengaruh $(P<0,05)$ terhadap bobot setahun. Paritas hanya berpengaruh terhadap bobot sapih. Tahun kelahiran dan musim sangat berpengaruh $(P<0,01)$ terhadap ketiga sifat pertumbuhan. Pendugaan nilai heritabilitas bobot lahir, bobot sapih, dan bobot setahun berturut-turut adalah $0,09 \pm 0,07 ; 0,33 \pm 0,09$; dan $0,43 \pm 0,10$. Nilai heritabilitas bobot sapih dan bobot setahun sapi Bali dikategorikan sedang sampai tinggi yang berarti seleksi terhadap kedua sifat tersebut akan efektif dalam meningkatkan kemajuan genetik sapi Bali.
\end{abstract}

Kata kunci: non genetik, heritabilitas, bobot lahir, bobot sapih dan setahun, sapi Bali

\section{ABSTRACT}

The aim of this study was to evaluate the effect of genetic and non-genetic factors on the growth traits including birth weight, weaning, and yearling weight of Bali cattle. Data were analyzed using generalized linear model (SAS) to observe non-genetic effect. To evaluate the genetic effect, the estimation of heritability were done using mixed models analysis with the dam and sire as random effect and sex, parity, year of birth, and season as fixed effect in the model besides the residual. The results showed that sex of calf had no significant influence on birth and weaning weight but had significant influence on yearling weight $(\mathrm{P}<0.01)$. Parity only affected weaning weight of calves and did not significantly effect on birth and yearling weight. Year of birth and season were significantly $(P<0.01)$ affected all traits considered in the study. With regard to the genetic effect, estimated heritability of birth, weaning, and yearling weight was $0.09 \pm 0.07,0.33 \pm 0.09$, and $0.43 \pm 0.10$ respectively. Heritability value of growth trait weaning and yearling weight in Bali cattle was quite moderate to high, so it was expected that selection in achieving increased gain on growth trait was effective.

Key words: non genetic, heritability, birth weight, weaning and yearling weight, Bali cattle

\section{INTRODUCTION}

Growth traits such as weaning and yearling weight are of primary economical importance in beef cattle production system. Animals with high growth potential are effectively affected progress selection program. Improvement of growth performances are important traits influencing profitability in the majority of beef pro-

\footnotetext{
* Corresponding author:

aagun4780@yahoo.com
}

duction systems. Bali cattle are one of several Indonesian native cattle that plays major role for beef production. The population of Bali cattle are recorded 3.271.000 in 2010 of which are $20 \%$ are concentrated at Bali province (Directorate General of Livestock Services, 2010). Bali cattle account for approximately $25 \%$ of the total cattle population in Indonesia (Lisson et al., 2010). Comparing to other breeds, Bali cattle have better adaptation capability especially in marginal environment (Zulkharnaim et al., 2010), have high fertility (80\%-82\%), high heterosis effect in crossbred (Noor et al., 2001) and have high meat quality and low fat percentage (Bugiwati, 2007). 
However, until recently a lot of national attention has been paid to the perceived weaknesses of Bali cattle, such as high calf mortality, small body size and slow growth rate. In order to achieve optimum genetic progress estimates of genetic effect like heritability related to growth traits such as birth weight, weaning and yearling weight are needed to develop a proper selection program.

Growth traits are easily measured and have medium to high heritability this suggesting that these traits are likely to respond to selection (Buzanskas et al., 2010). Meyer (1992) indicated that an animal model that includes individual performance and pedigree information would provide reliable estimates of genetic parameters and should result in improved genetic evaluation program. In addition, non-genetic effect also needs to include for appropriate ways to eliminate biases caused by them and hence more accurate estimation of genetic parameter. Knowledge of the non-genetic affect on production traits allows a more accurate assessment of response to selection. That is why for designing indigenous cattle such as Bali cattle improvement program, the data on genetic parameter estimates such as heritability of growth traits and non-genetic effect study are very important to realize.

Genetic parameter for growth traits such as heritability of daily gain, weaning and yearling weight of different beef cattle breeds have been reported by several studies (Utrera et al., 2011; Cucco et al., 2010; Demecke et al., 2003; Sukmasari et al., 2002; Praharani, 2009) Demecke et al. (2003) reported heritability of weaning weight in mixed population of purebred Bos indicus and crossbred cattle was 0.14. Cucco et al. (2010) obtained heritability of yearling weight of beef cattle of Braunvieh was 0.12 . However, information of genetic parameters related to growth traits of Indonesia local cattle such as Bali cattle were limited. Heritability values of weaning, yearling and daily gain of body weight Bali cattle were $0.23 \pm 0.02$; $0.38 \pm 0.02$, and $0.27 \pm 0.06$ respectively (Sukmasari et al., 2002). Praharani (2009) estimated heritability using an direct and maternal effect model in Bali cattle were 0.38 and 0.49 for BW205 (body weight 205 day) and BW365. Until now different studies showed higher heritability values recently reported for growth traits, but there are still lack of knowledge of the effects on these parameters and the genetic background. Comprehensive of information on genetic and non-genetic affect on growth traits of Bali cattle can improve selection method related to genetic quality of Bali cattle. This kind of study is important to devise their management practices for maximizing their productivity and genetic evaluation in Bali cattle. The aim of this study were to evaluate genetic and non-genetic effect of growth traits include birth weight, weaning and yearling weight of Bali cattle in Breeding Centre of Bali province.

\section{MATERIALS AND METHODS}

\section{Source of Data}

The data used in this study were collected from Breeding Centre of Bali cattle in Bali province during the period from September, 2005 to September, 2009.
Body weight data on individual animal was recorded at a regular basis of one month interval. The identities of newborns and of their parents, date of birth, sex of calf, parity, season and birth weight were recorded. The calf was weaned at about 205 days of age; accordingly, individual weaning weight was adjusted to 205 days of age. Data on weaning weight (WW) and one year weight (YW) at several calf ages were corrected based on 205 and 365-day age respectively. Data on birth weight of Bali cattle were available. The quotients used in weaning weight and one year weight correction based on 205 and 365-day age (BIF, 2002) were as follows:

WW205 : $\{[$ (actual weaning weight - birth weight)/actual age] $\times 205$ days + birth weight

YW365 : \{[(actual yearling weight - W205)/(actual age $-205)] \times 160$ days + W205

\section{Data Analysis}

Non-genetic effect. Growth traits included for this study was birth weight, weaning weight, and yearling weight. To assess the non-genetic effects on birth, weaning and yearling weight were analyzed using Generalized Linier Model (GLM) (Steel \& Torrie, 2005).

$$
Y=\mu+r i+s i+p i+q i+e
$$

Where:

$\mathrm{Y}$ = birth weight, weaning and yearling weight of Bali cattle

$\mu=$ overall mean

ri $=$ the effect of year birth $(2006,2007,2008,2009)$

si $=$ the effect sex of calf (male, female)

pi $=$ the effect of parity $(1,2,3,4,5)$

qi $=$ the effect of season (dry, rainy)

$\mathrm{e}=$ random error

The same statistical model was used to analyze birth, weaning and yearling weight including 2 way interactions such as year and season, parity and season. In all statistical models there were no two way interactions, therefore, final models considered only the main effects (Hammoud et al., 2010)

Genetic effect. To evaluate genetic effect, mixed models were performed to calculate the heritability of birth weight, weaning and yearling weight which enable the implementation of additional random effect. In the heritability model, sire and dam were included as a random effect in the model which account for the genetic effect. The total variance and covariance components were sorted into additive and non-additive (environmental and residual genetic) components (Meyer, 1992).

$$
Y_{i j k}=\mu+S_{i}+D_{i j}+E_{i j k}
$$

Where:

$\mu$ common mean

$S_{i}=$ effect of the $i^{\text {th }}$ sire

$D_{i j}=$ effect of the $i^{\text {th }}$ dam within the $i^{\text {th }}$ sire

$E_{i j k}=$ uncontrolled environmental deviations associated with each record which is assumed to be random, 
independent and normally distributed with a mean 0 and a common variance

Heritability was estimated from dam and sire variance components, according to Becker (1992) as follows:

$$
\mathrm{h}_{\mathrm{d}}^{2}=4 \delta_{\mathrm{d}}^{2} /\left(\delta^{2}{ }_{\mathrm{s}}+\delta_{\mathrm{d}}^{2}+\delta_{\mathrm{w}}^{2}\right) .
$$

Where:

$\mathrm{h}_{\mathrm{d}}^{2}=$ heritability from dam component

$\delta^{2}=$ sire variance component

$\delta^{2}{ }^{\mathrm{s}}=$ dam variance component

$\delta^{2}{ }_{\mathrm{w}}=$ within progeny variance component

Standard errors for heritability estimated were approximated following the method of the same author according to Becker (1992):

$$
\begin{gathered}
\mathrm{SE}\left(\mathrm{h}^{2} \mathrm{~s}+\mathrm{d}\right)=\frac{\sqrt[4]{\frac{2}{\mathrm{~K}_{3}{ }_{3}}\left[\frac{\mathrm{MS}^{2} \mathrm{~s}}{\mathrm{~S}-1+2}+\frac{\mathrm{MSd}^{2}}{\mathrm{~d}-\mathrm{s}+2}\right]}}{\mathrm{S}^{2} \mathrm{~T}} \\
\mathrm{~K}_{3}=\frac{1}{\mathrm{~S}-1}\left[\frac{\mathrm{N}-\sum \mathrm{n}^{2} 1}{\mathrm{n} 1}\right]
\end{gathered}
$$

Where:

$\mathrm{MS}_{\mathrm{D}}=$ mean square dam

$\mathrm{MS}_{\mathrm{s}}=$ mean square sire

$\mathrm{d}^{2}{ }_{\mathrm{T}}=$ total variance

$\mathrm{d}=$ number of dams

$\mathrm{s} \quad=$ number of sires

$\mathrm{K}_{3} \quad$ = number of progeny per sire

\section{RESULTS AND DISCUSSION}

\section{Non-Genetic Effects}

Mean along with their standard error (SE) of birth weight, weaning weight, and yearling weight were presented on Table 1.

Effect of sex. Sex of calf birth had no significant effect on birth and weaning weight but had significant effect on yearling weight $(\mathrm{P}<0.01)$. This result was in agreement which describing that sex had a highly significant influence on post weaning live weight and growth rate in Brahman cattle (Dadi et al., 2008). The influence of sex on live weight difference increased with age from $3.92 \mathrm{~kg}$ at weaning weight of age to $12.10 \mathrm{~kg}$ at yearling weight (Table 1). This might be attributed to different physiological processes in the two sexes. Their differences in growth rate increased with age implying that sex effects are more pronounced with age after puberty (Dadi et al., 2008).

Effect of parity. The effect of parity was significant $(\mathrm{P}<0.01)$ effect on weaning weight, but it had no significant effect on birth weight and yearling weight. It effect increased with increasing parity until the maximum of 9 to $12 \mathrm{~kg}$ live weight was recorded for weaning weight on parity 2 to 3 and 4 respectively. The influence of parity on live weight of calves was greatest at 3 and 4 , but decreased on parity 5 , as the calves grew older to yearling and above (Table 1). Calves of first parity until five were similar for birth weight and yearling weight. This might be explained by the fact that calves get less milk than average for the first time on birth weight. Morever, low of cow milk production as 1.51 per day for calves were found in Bali cattle (Belli, 2002). Post weaning growth such as yearling weight of cattle is partly determined by the direct genetic effect of the cattle and the level of non-genetic factors (Dadi et al., 2008). It is not surprising that post weaning weights at yearling weight were not significantly affected by parity. The effect of parity was significant for weaning weight is expected influence of the maternal ability to be high for weaning weight. Postnatal factors account for $75 \%$ of the maternal influence on weaning weight and are largely mediated through milk production (Dadi et al., 2008).

Effect of year. Effect year of birth had significant at birth weight, weaning weight, and yearling weight. Year of birth significantly $(\mathrm{P}<0.01)$ influenced at birth weight, weaning weight, and yearling weight with a trend of 2007>2008>2006 (Table 1). Differences observed in weights between years may be a reflection of differences in feed availability among years due to by variation in total annual precipitation and the distribution of rainfall in breeding centre. The significant effect of year could be attributed to variability in management and climate especially between different years (Haile et al., 2009). Similar results of the effect of year on weaning and yearling reflected the variations on nutrition and management for the animals in the local region where the flock was located (Zhou et al., 2003).

Effect of season. Season of birth had significant effect on birth weight, weaning weight, and yearling weight. The trend of weight on seasons was rainy>dry for birth weight and dry> rainy for weaning weight and yearling weight. Calves born during rainy season were heavier than those born during rainy season. This variation is due to the availability of pastures to the pregnant dams. In case of weaning and yearling weight, calves born in the dry season heavier had $3.22 \mathrm{~kg}$ and $7.73 \mathrm{~kg}$ live weight at weaning and yearling weight respectively of age than those born in rainy season though feed availability is relatively better in rainy season. Thus, from the results of this study it is evident that calves born in the dry season perform better than those born in the other seasons. Praharani (2009) also reported that season had a significant effect on weaning and yearling growth performances of Bali cattle. A possible explanation for this is that, in the rainy season the forages are succulent (Dadi et al., 2008). Furthermore, disease challenge is high in wet season (Gemeda et al., 2005) contributing further to lower live weight at weaning. Effect of season on weaning and yearling weight also reflected management such as mating, housing and feeding for the animals in the local region where the flock was located (Gunawan \& Noor, 2005).

\section{Genetic Effect}

With regard to the genetic effect, estimated heritability of birth weight, weaning weight, and yearling 
Table 1. Mean along with their standard error (SE) for birth weight, weaning, and yearling weight (kg)

\begin{tabular}{cccc}
\hline \multirow{2}{*}{ Sex of calf } & \multicolumn{4}{c}{ Trait } \\
\cline { 2 - 4 } Male & Birth weight $(\mathrm{n})$ & Weaning weight $(\mathrm{n})$ & Yearling weight $(\mathrm{n})$ \\
\hline Female & $17.73 \pm 1.72(121)$ & $89.50 \pm 8.80(110)$ & $142.45 \pm 3.25^{\mathrm{A}}(79)$ \\
Parity: & $17.55 \pm 1.70(115)$ & $85.58 \pm 9.61(105)$ & $130.25 \pm 2.58^{\mathrm{B}}(89)$ \\
1 & & & \\
2 & $17.65 \pm 1.43(72)$ & $84.62 \pm 9.22^{\mathrm{A}}(63)$ & $134.45 \pm 3.31(60)$ \\
3 & $17.15 \pm 1.82(73)$ & $83.71 \pm 8.61^{\mathrm{A}}(68)$ & $140.80 \pm 4.30(45)$ \\
4 & $17.69 \pm 1.76(55)$ & $92.41 \pm 9.30^{\mathrm{B}}(49)$ & $135.16 \pm 4.11(38)$ \\
5 & $18.64 \pm 1.56(28)$ & $94.48 \pm 10.16^{\mathrm{B}}(27)$ & $134.90 \pm 7.84(20)$ \\
Year: & $18.66 \pm 1.86(7)$ & $90.33 \pm 6.07^{\mathrm{B}}(7)$ & $135.00 \pm 5.00(3)$ \\
2006 & & & $147.72 \pm 3.46^{\mathrm{A}}(58)$ \\
2007 & $16.29 \pm 1.13^{\mathrm{A}}(63)$ & $81.47 \pm 8.26^{\mathrm{A}}(59)$ & $155.12 \pm 5.13^{\mathrm{A}}(25)$ \\
2008 & $17.12 \pm 1.51^{\mathrm{B}}(74)$ & $89.04 \pm 9.79^{\mathrm{B}}(73)$ & $123.75 \pm 2.50^{\mathrm{B}}(85)$ \\
2009 & $18.90 \pm 1.23^{\mathrm{C}}(98)$ & $90.61 \pm 9.32^{\mathrm{B}}(85)$ & - \\
Season: & $17.57 \pm 3.89^{\mathrm{B}}(106)$ & - & \\
Dry & $17.43 \pm 1.72^{\mathrm{A}}(172)$ & $88.50 \pm 8.23^{\mathrm{A}}(159)$ & $138.26 \pm 3.46^{\mathrm{A}}(144)$ \\
Rainy & $18.25 \pm 1.53^{\mathrm{B}}(63)$ & $84.98 \pm 8.35^{\mathrm{B}}(56)$ & $130.53 \pm 5.69^{\mathrm{B}}(34)$ \\
\hline
\end{tabular}

Note: means in the same column with different superscript differ significantly $(\mathrm{P}<0.01)$. n= number of animal.

weight of the present study were $0.09 \pm 0.07 ; 0.33 \pm 0.09$; and $0.43 \pm 0.10$, respectively (Table 2).

Birth weight. Heritability estimates for birth weight of Bali cattle breed were 0.09 \pm 0.07 (Table 2). These estimates are lower than those usually found in literature for tropical cattle. Estimation heritability of birth weight was reported in Santa Gertrudis and Brahman cattle to be 0.16 and 0.33 respectively (Please et al., 2002). Albuqurque (2001) reported 0.28 for birth weight of Zebu cattle. Azis et al. (2005) also reported heritability for birth weight of Japanese Black to be 0.38 and 0.48 respectively. However, this value of birth weight heritability was be closely in agreement with data $(0.10 \pm 0.05)$ reported by Abdullah \& Olutogun (2006) for N'Dama cattle and $0.10 \pm 0.002$ by Shehu et al. (2008) in Nigerian cattle. Differences found among result are probably due to breed differences, statistical analysis (animal or sire models), selection pressure within population, sample size and environmental effect (Abdullah \& Olutogun, 2006). Similar results of the discrepancies of the value could be due to differences in genetic variation among the populations, differences in statistical models used for analysis of the same breed to different environmental conditions (Makgahlela et al., 2008). Shehu et al. (2008) reported the low values of heritability obtained could be either due to deterioration in management resulting to poor nutritional status of the animals, or due to the use of same sire for a number of years which could result in inbreeding and decrease in additive genetic variation.

Heritability value for birth weight of Bali cattle in this study was within the range of published values (Abdullah \& Olutogun, 2006; Shehu et al., 2008). The estimates of heritability from literature were close of the estimated in this study, suggesting that all studied traits could be included in beef cattle improvement programs, because the direct selection for any trait could result in genetic progress. Low heritability values of birth weight suggested that selection on the basis of individual performance will not be effective in achieving increased gain in birth weight. Chen et al. (2003) argued that the low rates of genetic progress such as on birth weight was because breeders were not selecting them or that the selection applied was ineffective because of lower heritability. Lower heritability value of may be due to small number of data or erratic nature of birth

Table 2. Estimates of heritability of birth weight, weaning, and yearling weight of Bali cattle

\begin{tabular}{lccrrr}
\hline \multicolumn{1}{c}{ Traits } & Number of animal & $\mathrm{h}^{2} \pm \mathrm{SE}$ & $\mathrm{V}_{\mathrm{A}}$ & $\mathrm{V}_{\mathrm{E}}$ & \multicolumn{1}{c}{$\mathrm{V}_{\mathrm{P}}$} \\
\hline Birth weight & 358 & $0.09 \pm 0.07$ & 0.15 & 1.62 & 1.66 \\
Weaning weight (205) & 218 & $0.33 \pm 0.09$ & 306.69 & 851.13 & 927.80 \\
Yearling weight (365) & 179 & $0.43 \pm 0.10$ & 698.36 & 1.424 .10 & 1598.69 \\
\hline
\end{tabular}

Note: $\mathrm{h}^{2}=$ heritability; $\mathrm{V}_{\mathrm{A}}=$ variance of aditive; $\mathrm{V}_{\mathrm{E}}=$ variance of environment; $\mathrm{V}_{\mathrm{P}}=$ variance of phenotypic. 
weight which impact to large standard error. High standard error due high difference between maximum and minimum range of birth weight observed within the Bali cattle calves because of on-station environmental stress faced by their dams during feeds crisis period (Rabeya et al., 2009). Goyache \& Guiterez (2001) also explained the lower heritability might be due to 1) little number of animals available in estimations, 2) the existence of a very important environmental influence on these traits, 3) the need for better adjustment of fixed effects, 4) failure to consider the influence of some other reproduetive traits on birth weight.

Weaning weight. Estimated heritability in Bali cattle for weaning weight was $0.33 \pm 0.09$ (Table 2). Praharani (2009) reported heritability of weaning weight used singletrait or multiple-trait analyses with range of $0.30-0.39$. Prediction of heritability for growth trait of Bali cattle in this study also was included in range of weaning weight of beef cattle as summarized by Groeneveld et al. (1998).

Heritability of weaning weight in this study is higher than those usually in previous study. Sukmasari et al. (2002) obtained heritability of $0.23 \pm 0.02$ for weaning weight. Genetic variance was influenced by differences in data number (structure) analyzed, genetic analysis method, connectedness (relationship among cattle groups), and research time (Clement et al., 2001). Result of heritability weaning weight in this study was quite moderate, so it was expected that selection on growth trait was effective. Heritability value for weaning weight of the present study was within the range of published values. High heritability values of weaning weight suggest that selection on the basis of individual performance will be effective in achieving increased gain in weaning weight.

Yearling weight. The calculated heritability for direct genetic effect of yearling weight was $0.43 \pm 0.10$ (Table 2). Heritability value in this study was classified high because more than 0.4 (Noor, 2010). This result is lower than most previous estimates founded in the literature. According to Praharani (2009), ranged the heritability for yearling weight direct genetic effect between 0.490.54. Ardike (1995) obtained a yearling weight heritability of Bali cattle was 0.58 . Nevertheless, these estimates are higher than the value obtained by Sukmasari et al. (2002) found from Bali cattle using BLUP analysis to be $0.38 \pm 0.02$. This indicated the existence of a relatively high additive genetic variable and therefore, a rapid genetic improvement of the management practice should be achieved (Estrada-Leon et al., 2008). High heritability values of yearling weight suggest that selection on the basis of individual performance will be effective in achieving increased gain in yearling weight.

In this study estimation heritability of weaning weight was lower than that of yearling weight. This result in agreement with previous study describing heritability of weaning weight was lower than that of yearling weight (Albuquerque \& Meyer, 2001). Result of this heritability value showed that genetic variance of growth trait weaning and yearling weight in Bali cattle was quite moderate to high, so it was expected that selection on growth trait was effective (Praharani, 2009).

\section{CONCLUSION}

Non-genetic factor influence the variability of birth weight, weaning and yearling weight in Bali cattle suggest strengthening management for Bali cattle under the extensive conditions in the local region. With regard to the genetic effect, estimated heritability of weaning and yearling weight were considered moderate $(0.33$ and 0.43 ), which means that the selection program will be more effective and efficient in improving the genetic merits in Bali cattle.

\section{ACKNOWLEDGEMENT}

The authors are grateful to Breeding Centre BPTU especially to Yudi Parwoto, S.Pt. and Drh. Eddy Suprapto who were responsible for providing the full data and support.

\section{REFERENCES}

Abdullah, A. R. \& O. Olutogun. 2006. Estimates of genetic and phenotypic parameters for preweaning growth traits of N'Dama (Bos Taurus) calves in the humid tropics of Nigeria. Livest. Res. Rur. Develop. http://www.cipav.org. $\mathrm{co} / \mathrm{lrrd} / \mathrm{lrrd} 18 / 8 / \mathrm{ab}$ du18120.htm [1 December 2006]

Albuquerque, G. L. 2001. Etimates of direct and maternal genetic effects for weight from birth to 600 days of age in Nelore cattle. J. Anim. Breed. Genet.118: 83-92

Albuquerque, L. G. \& K. Meyer. 2001. Estimates of covariance functions for growth from birth to 630 days of age in Nelore cattle, J. Anim. Sci.79: 2776-2789.

Aziz, M. A., S. Nishida, K. Suzuki, \& A. Nishada. 2005. Estimation of direct and maternal genetic and permanent environmental effects for weights from birth to 356 days of age in a herd of Japanese Black cattle using random regression. J. Anim. Sci. 83: 519-530

Becker, W. A. 1992. Manual of Quantitative Genetics, $5^{\text {th }}$ ed Academic Enterprises., USA.

Belli, H. L. L. 2002. Supplementaion to improve the performance of grazing Bali cows (Biboss banteng Wagner). Disertation. Graduate School. University of Gottingen, Goettingen.

BIF (Beef Improvement Federation). 2002. Guidelines for Uniform Beef Improvement Programs. $8^{\text {th }}$ ed. Kansas State Univ., Kansas.

Bugiwati, S. R. A. 2007. Body dimension growth of calf bull in Bone and Baru District, South Sulawesi. J. Sains and Tekno. 7: 103-108

Buzanskas, M. E., D. A. Grossi, F. Baldi, L. O. C. Silvi, R. A. A. Torres Junior, D. P. Munari, \& M. Alencar. 2010. Genetic associations between stayibility and reproductive and growth traits in Canchim beef catlle. Livest. Sci. 132: 107-112.

Chen, P., T. J. Baas, J. W. Mabry, K. J. Koelher, \& J. C. M. Dekkers. 2003. Genetic parameters and trends for litter traits in U.S. Yorkshire, Duroc, Hampshire, and Landrace pigs. J. Anim. Sci 81: 46-53.

Clement, V., B. Bibe, E. Verrier, J. M. Elsen, E. Manfredi, J. Bouix, \& E. Hanocq. 2001. Simulation analysis to test the influence of model adequacy and data structure on the estimation of genetic parameters for traits with direct and maternal effects. Genet. Sel. Evol. 33: 369-395. 
Cucco, D. C., J. B. S. Ferraz., J. P. Eler., J. C. C. Baliero, E. C. Mattos., \& L. Varona. 2010. Genetic parameters for post weaning traits in Braunvieh cattle. Genet. Mol. Res. 9: 545-553.

Dadi, H., G. Duguma, B. Shelima, T. Fayera, M. Tadesse, T. Woldu, \& T. A. Tucho. 2008. Non-genetic factors influencing post-weaning growth and reproductive performances of Arsi-Bale goats. Livest. Res. Rur. Develop. Article \#114. Retrieved http://www.lrrd.org/lrrd20/7/dadi20114.htm [3 September 2009]

Demeka, S., F. W. C. Neser., \& S. J. Schoeman. 2003. Variance components and genetic parameters for early growth traits in a mixed population of purebred Bos indicus and crossbred cattle. Livest. Prod. Sci. 84:11-21.

Directorate General of Livestock Services. 2010. Indonesian Statistical Book on Livestock 2010. Directoral General of Livestock Services. Jakarta

Estrada-Leon, R. J., J. G. Magana, \& J. C. Segura-Correa. 2008. Genetic parameter for reproductive traits of Brown Swiss cows in the tropics of Mexico. J. Anim. Vet Adv.7:124-129

Gemeda, D., K. Takele, G. Ulfina, A. Solomon, \& G. Gebregziabher. 2005. Mortality and reported clinical signs in Horro sheep at smallholder farms in east Wollega and west Shoa zones, Ethiopia. Ethiop. J. Anim. Product. 5: $33-42$

Goyache, F. \& J. P. Gutierrez. 2001. Heritability of reproductive traits in Asturiana de los Valles beef cattle breed. Arch. Tierz. Dummerstorf. 445: 489-496

Groeneveld, E., B. E. Mostert, \& T. Rust. 1998. The covariance structure of growth traits in the Africaner beef population. Livest. Prod. Sci. 55: 99-107.

Gunawan, A. \& R. R. Noor. 2006. Estimation heritability of birth and weaning weight of the fighting type of Garut sheep. Med. Pet. 29: 7-15

Haile A., B. K. Joshi, W. Ayalew, A. Tegegne, \& A. Singh. 2009. Genetic evaluation of Ethiopian Boran cattle and their crosses with Holstein Friesian in central Ethiopia: reproductive traits. J. Agric Sci. 147: 81-89

Hammoud, M. H., S. Z. El-Zarkouny1, \& E. Z. M. Oudah. 2010. Effect of sire, age at first calving, season and year of calving and parity on reproductive performance of Friesian cows under semiarid conditions in Egypt. Arch. Zootech. 13: 60-82.

Lisson, S., N. MacLeod, C. McDonald, J. Corfield, B. Pengelly, L. Wirajaswadi, R. Rahman, S. Bahar, R. Padjung, N. Razak, K. Puspadi, Dahlanuddin, Y. Sutaryono, S. Saenong, T. Panjaitan, L. Hadiawati, A. Ash, \& L.
Brennan. 2010. A participatory, farming systems approach to improving Bali cattle production in the smallholder crop-livestock systems of Eastern Indonesia. Agricult. Sys. 103: $486-497$

Makgahlela, M. L., C. B. Banga. D. Norris. K. Dzama, \& W. Ngambi. 2008. Genetic analysis of age at first calving and calving interval in South African Holstein cattle. Asia J. Anim. Vet. Adv. 3: 197-205

Meyer, K. 1992. Variance components due to direct and maternal effects for growth traits of Australian beef cattle. Livest. Prod. Sci.31: 179-204.

Noor, R. R. 2010. Genetika Ternak. $6^{\text {th }}$ ed. Penebar Swadaya, Jakarta.

Noor, R. R., A. Farajallah, \& M. Karmita. 2001. The purity test of Bali cattle by haemoglobin analysis using the isoelectric focusing method. Hayati. 8:107-111

Pleasse, D., O.Verde, H. Fossi, R. Romero, R. Hoogestejin, P. Bastidas, \& J. Bastardo. 2002. (Co) variance components, genetics parameter and annual trends for calf weights in a pedigree Brahman herd under selection for 3 decades. J. Anim. Breed. Genet.119: 141-153.

Praharani, L. 2009. Estimation of direct and maternal weights in Bali cattle effect for weaning and yearling. Indonesia. J. Agric. 2: 74-81

Rabeya, T., A. K. F. H. Bhuiyan, M. A. Habib, \& M. S. Hossain. 2009. Phenotypic and genetic parameters for growth traits in Red Chittagong Cattle of Bangladesh. J. Bangladesh. Agric. Unive. 7:265-271.

Shehu, D. M., O. O. Oni, S. A. S. Olorunju, \& I. A. Adeyinka. 2008. Genetic and phenotypic parameters for body weight of Sokoto Gudali (Bokoloji) cattle. Int. Jor. P. App. Scs., 2: 64-67

Sukmasari, A. H., R. R. Noor, H. Martojo, \& C. Talib. 2002. The estimation of breeding values and genetics trends of body weight in Bali cattle improvement project. Hayati. 9: 109-113.

Utrera., A. R., V. E. V. Murillo., G. M. Velazquez, \& M. M. Bermudez. 2011. Comparison of models for the estimation variance components for growth traits of registered Limousin cattle. Trop. Subtrop. Agroeco. 14:667-674.

Zhou, H. M., D. A. Ain, J. Q. Li, W. G. Zhang, \& X. C. Yu. 2002. Genetic parameters of production traits of Inner Mongolia cashmere goats in China. J. Anim. Breed. Genet. 119: 385-390.

Zulkharnaim, Jakaria, \& R. R. Noor. 2010. Identification of genetic diversity of growth hormone receptor (GHR $\mid$ Alu I) gene in Bali cattle. Med. Pet. 33: 81-87 